\title{
Lysobacter oryzae sp. nov., isolated from the rhizosphere of rice (Oryza sativa L.)
}

\begin{abstract}
Correspondence Young Ryun Chung yrchung@gnu.ac.kr
\end{abstract}

\author{
Zubair Aslam, ${ }^{1}$ Muhammad Yasir, ${ }^{1}$ Che Ok Jeon ${ }^{2}$ \\ and Young Ryun Chung ${ }^{1}$ \\ ${ }^{1}$ Division of Applied Life Science (BK 21), PMBBRC and EB-NCRC, Gyeongsang National \\ University, Jinju 660-701, Republic of Korea \\ ${ }^{2}$ Department of Life Science, Chung-Ang University, Seoul 156-756, Republic of Korea
}

The taxonomic position of a novel bacterial strain, $\mathrm{YC} 6269^{\top}$, isolated from the rhizosphere of rice (Oryza sativa L.) managed under no-tillage practice in Jinju, South Korea, was studied using polyphasic approach. Cells of the strain were Gram-negative, rod-shaped and facultatively anaerobic. The novel strain grew at a temperature of $15-42{ }^{\circ} \mathrm{C}$ (optimum at $28{ }^{\circ} \mathrm{C}$ ). Growth of the strain occurred between $\mathrm{pH} 5.5$ and 11.0, with an optimum at $\mathrm{pH}$ 7.0-8.0. The $\mathrm{G}+\mathrm{C}$ content of the total DNA was $67.4 \mathrm{~mol} \%$. The 16S rRNA gene sequence of the strain was most closely related to species of the genus Lysobacter, Lysobacter yangpyeongensis DSM $17635^{\top}(98.6 \%)$, Lysobacter niabensis GH34-4 ${ }^{\top}$ (97.2\%), Lysobacter enzymogenes DSM $2043^{\top}(96.9 \%)$, Lysobacter daejeonensis DSM $17634^{\top}$ (96.3\%) and Lysobacter niastensis GH41-7 ${ }^{\top}$ (96.2 \%). The novel strain showed $<96.0 \%$ similarity with other species of the genus Lysobacter. Chemotaxonomic data (major quinone, Q-8; major polar lipids, phosphatidylethanolamine, phosphatidylglycerol and phosphatidyl- $N$-methylethanolamine, and major fatty acids, $\mathrm{C}_{15: 0}$ iso, $\mathrm{C}_{16: 0}$ iso, $\mathrm{C}_{17: 0}$ iso and $\mathrm{C}_{17: 1}$ iso $\left.\omega 9 \mathrm{c}\right)$ supported the affiliation of strain $\mathrm{YC} 6269^{\top}$ to the genus Lysobacter. Phylogenetic analysis based on the 16S rRNA gene sequences, DNA-DNA hybridization data and biochemical and physiological characteristics strongly supported the genotypic and phenotypic differentiation of strain $\mathrm{YC} 6269^{\top}$ from recognized species of the genus Lysobacter. Strain YC6269 ${ }^{\top}$, therefore, represents a novel member of the genus Lysobacter, for which the name Lysobacter oryzae sp. nov. is proposed. The type strain is $\mathrm{YC} 6269^{\top}(=\mathrm{KCTC}$ $22249^{\top}=$ DSM $21044^{\top}$ ).
The genus Lysobacter, grouped in the family Xanthomonadaceae belongs to the class Gammaproteobacteria. Species of the genus Lysobacter were originally grouped with myxobacteria because they shared the distinctive trait of gliding motility, but they display a number of unique traits that distinguish them from other taxonomically and ecologically related microbes, including high genomic DNA G $+\mathrm{C}$ content (typically ranging between 65.4 and $70.1 \mathrm{~mol} \%$ ) and a lack of flagella (Christensen \& Cook, 1978). Interest in members of the Lysobacter group has increased recently as they have potential for the development of biocontrol agents against plant fungal pathogens (Folman et al., 2004; Islam et al., 2005; Kilic-Ekici \& Yuen, 2003; Nakayama et al., 1999; Park et al., 2008) and antibiotic compounds

The GenBank/EMBL/DDBJ accession number for the $16 \mathrm{~S}$ rRNA gene sequence of strain YC6269 ${ }^{\top}$ is EU376963.

A transmission electron micrograph of cells of strain $\mathrm{YC} 6269^{\top}$ and the TLC polar lipid analysis are available as supplementary figures with the online version of this paper. Additional tables detailing the enzymic activities of the novel strain and the fatty acid profile are also available. against human pathogens (Ahmed et al., 2003; Chohnan et al., 2002; Hashizume et al., 2004; Kato et al., 1998).

Species of the genus Lysobacter have been described as ubiquitous inhabitants of soil and water and are commonly found in diverse geographical and environmental habitats (Christensen \& Cook, 1978; J. W. Lee et al., 2006; Lueders et al., 2006; Romanenko et al., 2008; Weon et al., 2006, 2007; Yassin et al., 2007). Recently, their relevance to agriculture has been recognized and their roles as members of significant microbial communities associated with soil and plants have been explored (Folman et al., 2001; Islam et al., 2005; J. W. Lee et al., 2006; M. S. Lee et al., 2006; Park et al., 2008).

During the analysis of the bacterial communities of two rice fields managed under conventional and no-tillage practices, many unknown strains were isolated by using a modified culture method and an improved isolation methodology. Some novel strains which belong to the genus Lysobacter were isolated by the improved culture method from the rhizosphere of rice at different growth 
phases from the no-tillage field, but not from the conventional tillage field.

The improved culture method was based on a combination of factors such as longer incubation, sonication, selection of microcolonies with the help of magnifying lens, increasing the number of inoculation plates of each dilution, using modified half-strength R2A agar and some additional modifications (Hamaki et al., 2005; Janssen et al., 2002; Joseph et al., 2003). The modified half-strength R2A agar consisted of $0.25 \mathrm{~g}$ yeast extract, $0.25 \mathrm{~g}$ proteose peptone No. 3 (Difco), $0.25 \mathrm{~g}$ Casamino acid, $0.25 \mathrm{~g}$ glucose, $0.25 \mathrm{~g}$ soluble starch, $0.15 \mathrm{~g}$ sodium pyruvate, $0.15 \mathrm{~g} \mathrm{~K}_{2} \mathrm{HPO}_{4}, 0.03 \mathrm{~g} \mathrm{MgSO}_{4}, 25 \%$ soil extract (v/v) and $15 \mathrm{~g}$ agar in 11 of distilled water. Three soil samples were collected from the rhizosphere of the rice from each field at three growth phases, vegetative, reproductive and ripening, from Gyeongsang National University farm (Daegok valley) located in the north-east of Jinju, Korea, during 2007. One sample was collected at the zero-phase (presowing) from both fields. The rhizosphere samples were collected at a depth of 15-20 cm and from an area 6-10 cm wide from five randomly selected points in each field after the removal of the upper $3-5 \mathrm{~cm}$ soil, some straw and debris. After sonication and serial dilution in $50 \mathrm{mM}$ phosphate buffer ( $\mathrm{pH} 7.0$ ), the samples were spread on modified half-strength R2A agar plates. Plates were incubated at $28{ }^{\circ} \mathrm{C}$ for longer than one month. Single colonies on the plates were purified by transferring them onto new plates and these were incubated again on halfstrength R2A (without soil extract) agar. One novel bacterial strain, YC6269 ${ }^{\mathrm{T}}$, was isolated from the rhizosphere sample collected at the ripening phase from the notillage field. The novel strain was identified on the basis of $16 \mathrm{~S}$ rRNA gene sequences, DNA-DNA hybridization data and other chemotaxonomic and genotypic characteristics (Park et al., 2008). It was confirmed that this new strain represents a novel species in the genus Lysobacter. The novel strain was routinely cultured on half-strength R2A agar at $28{ }^{\circ} \mathrm{C}$ and maintained as a glycerol suspension $(15 \%, w / v)$ in half-strength R2A broth at $-70{ }^{\circ} \mathrm{C}$.

Cell morphology was observed using light (Nikon; $\times 1000)$ and transmission electron microscopy (model H-600; Hitachi) with cells grown for 1 day at $28{ }^{\circ} \mathrm{C}$ in halfstrength R2A broth. Catalase and oxidase tests were performed by the procedures as outlined by Cappuccino \& Sherman (2002). The physiological properties of strain YC6269 $9^{\mathrm{T}}$ were determined using previously described tests for hydrolysis of casein, aesculin, gelatin, starch and urea (Brown, 2007), hippurate (Kinyon \& Harris, 1979), elastin (Ohman et al., 1980), guanine and adenine (Wallace et al., 1995), cellulose (Ten et al., 2004) and Tween 20 (Atlas, 1993). Enzyme activities and acid production from different carbohydrates were determined by using API ZYM and API 20E kits, respectively, at $37{ }^{\circ} \mathrm{C}$ according to the manufacturer's instructions (bioMérieux). API ZYM strips were read after $5 \mathrm{~h}$ incubation. The assimilation of single carbon substrates was determined by using ID $32 \mathrm{E}$ and API 20NE kits at $30{ }^{\circ} \mathrm{C}$ after $24 \mathrm{~h}$ incubation. Growth at different temperatures $\left(4,15,20,28,37\right.$ and $\left.42{ }^{\circ} \mathrm{C}\right)$ was tested on half-strength R2A agar. Anaerobic growth was tested at $28{ }^{\circ} \mathrm{C}$ by pouring a thick layer of vaspar $(50 \%$ petrolatum, $50 \%$ paraffin) on the surface of inoculated half-strength R2A broth in $35 \mathrm{ml}$ screw capped glass tubes (Costilow, 1981). Growth at different temperatures and $\mathrm{pH}$ was assessed after 3 days incubation. Salt tolerance was tested in half-strength R2A broth medium supplemented with $1-10 \%(w / v) ~ N a C l$ after 7 days incubation. Duplicate antibiotic sensitivity tests were performed using filterpaper discs containing the following: tetracycline, kanamycin, ampicillin, streptomycin and rifampicin, each with 10,50 and $100 \mu \mathrm{g} \mathrm{ml}^{-1}$ concentrations. Discs were placed on half-strength R2A agar plates spread with strain YC $6269^{\mathrm{T}}$ and reference strains and the plates were then incubated at $28{ }^{\circ} \mathrm{C}$ for 3 days. Almost all tests were performed with closely related reference strains including Lysobacter antibioticus KCTC $12129^{\mathrm{T}}$, Lysobacter daejeonensis DSM $17634^{\mathrm{T}}$, Lysobacter enzymogenes KCTC $12131^{\mathrm{T}}$, Lysobacter gummosus KCTC $12132^{\mathrm{T}}$, Lysobacter koreensis KCTC $12204^{\mathrm{T}}, \quad$ Lysobacter niabensis $\mathrm{GH} 34-4^{\mathrm{T}}$ and Lysobacter yangpyeongensis DSM $17635^{\mathrm{T}}$.

Extraction of genomic DNA was performed using a commercial genomic DNA extraction kit (Core Biosystem). The 16S rRNA gene of strain YC6269 $9^{\mathrm{T}}$ was PCR amplified from a small amount $(0.5 \mu \mathrm{l})$ of purified genomic DNA by using a set of primers 27F and 1492R (Lane, 1991). The PCR product obtained was purified and sequenced according to Chung et al. (1999). The 16S rRNA gene sequences were compiled using SeqMan software (DNASTAR) and the sequences of related taxa were obtained from the GenBank database. The multiple alignments were performed by CLUSTAL_X program (Thompson et al., 1997). Gaps were edited in the BioEdit program (Hall, 1999). The evolutionary distances were calculated using the Kimura two-parameter model (Kimura, 1983). The phylogenetic trees were constructed by using a neighbour-joining method (Saitou \& Nei, 1987) and maximum-parsimony (Fitch, 1971) in the MEGA4 program (Tamura et al., 2007) with bootstrap values based on 1000 replications (Felsenstein, 1985).

For the measurement of the $\mathrm{G}+\mathrm{C}$ content of chromosomal DNA, the genomic DNA of the novel strain was extracted and purified as described by Ausubel et al. (1995). It was then enzymically degraded into nucleosides and $\mathrm{G}+\mathrm{C}$ content was determined as described by Mesbah et al. (1989) using a reverse-phase HPLC. Cellular fatty acids were analysed using samples of Lysobacter species grown on R2A agar for 2 days at $28{ }^{\circ} \mathrm{C}$. Cellular fatty acids were saponified, methylated and extracted according to the protocol of the Sherlock Microbial Identification System version 4.0 software (MIDI). The fatty acids analysed by GC (Hewlett Packard 6890) were identified using the Microbial Identification software package. The quinone system and the polar lipids were determined by TLC, as described previously (Lechevalier et al., 1977; Tindall, 1990). 
DNA-DNA hybridization was carried out to evaluate the genomic DNA relatedness between strain $\mathrm{YC} 269^{\mathrm{T}}$ and the most closely related species of the genus Lysobacter (as determined by $16 \mathrm{~S}$ rRNA gene sequence similarity of $>97.0 \%$ ) to strain YC6269 ${ }^{\mathrm{T}}$ (Stackebrandt \& Goebel, 1994; Wayne et al., 1987). It was performed with photobiotinlabelled probes in microplate wells as described by Ezaki et al. (1989), using a FLX 800 microplate fluorescence reader (Bio-Tek) for fluorescence measurements. The hybridization temperature was $65.3{ }^{\circ} \mathrm{C}$ and reciprocal experiments were performed with strain $\mathrm{YC} 269^{\mathrm{T}}, L$. yangpyeongensis DSM $17635^{\mathrm{T}}$ and L. niabensis GH34- $4^{\mathrm{T}}$. Hybridization was conducted with five replications for each sample. The highest and lowest values obtained for each sample were excluded and the remaining three values were utilized in the calculation of similarity values. The DNA relatedness values quoted are expressed as the means of these three values.

The novel strain was Gram-negative, non-motile and had gliding activity. Cells were short, rod-shaped (0.3$0.5 \times 1.8-2.0 \mu \mathrm{m}$; see Supplementary Fig. S1, available in IJSEM Online) and occurred singly and in pairs. Colonies grown on half-strength R2A agar plates for 3 days were smooth, circular, pale yellow, $1-2 \mathrm{~mm}$ in diameter and changed form as they grew older due to the gliding motility. Fruiting bodies were not observed. Growth was facultatively anaerobic. The novel strain grew well on R2A agar, nutrient agar, $1.0 \%$ trypticase soy broth $(\mathrm{w} / \mathrm{v})$ (plus $1.5 \%$ agar) and eosin methylene blue (EMB) agar, but did not grow on MacConkey agar, full-strength trypticase soy agar or LB agar. All culture media were from Difco. The physiological characteristics of strain $\mathrm{YC} 6269^{\mathrm{T}}$ are summarized in the species description and a comparison of selective characteristics with related type strains is presented in Table 1. Enzymic activities are given in the species description and a comparison of these with closely related type strains of the genus Lysobacter is given in Supplementary Table S1 (available in IJSEM Online).

The cellular fatty acid profiles of strain $\mathrm{YC} 6269^{\mathrm{T}}$ and related type strains of the genus Lysobacter are shown in Supplementary Table S2 (see IJSEM Online). The major cellular fatty acids for strain $\mathrm{YC} 6269^{\mathrm{T}}$ included $\mathrm{C}_{17: 1}$ iso $\omega 9 c(21.5 \%), \mathrm{C}_{16: 0} \mathrm{~N}$ alcohol (16.3\%), $\mathrm{C}_{15: 0}$ iso (12.5\%), $\mathrm{C}_{17: 0}$ iso $(12.3 \%), \mathrm{C}_{16: 0}$ iso $(8.5 \%), \mathrm{C}_{15: 1}$ iso $\mathrm{AT} 5$ (3.9\%), $\mathrm{C}_{11: 0}$ iso $(3.9 \%), \mathrm{C}_{16: 1} \omega 7 c$ alcohol $(3.5 \%), \mathrm{C}_{11: 0}$ iso $3-\mathrm{OH}(3.2 \%), \mathrm{C}_{14: 0}(2.8 \%), \mathrm{C}_{16: 0}(2.7 \%), \mathrm{C}_{15: 0}$ anteiso $(2.2 \%), \mathrm{C}_{16: 1} \omega 11 \mathrm{c}(2.1 \%), \mathrm{C}_{15: 0}$ iso $3-\mathrm{OH}$ $(1.9 \%)$, summed feature $3(1.1 \%)$ and trace amounts $(<1.0 \%)$ of some other fatty acids were detected. Although the major fatty acids were similar to those found for other members of the genus Lysobacter, differences were found between some species in the genus Lysobacter and the novel strain. Fatty acids $\mathrm{C}_{16: 0} \mathrm{~N}$ alcohol and $\mathrm{C}_{15: 0}$ iso $3-\mathrm{OH}$ were detected only in strain YC6269 ${ }^{\mathrm{T}}$ (Supplementary Table S1). The following polar lipids were present: phosphatidylethanolamine, phosphatidylglycerol, phosphatidyl- $N$-methylethanolamine and some unknown amino group-containing lipids (see Supplementary Fig. S2 in IJSEM Online), demonstrating the relatedness of the novel strain to the genus Lysobacter (Park et al., 2008).

The DNA G +C content of strain YC6269 ${ }^{\mathrm{T}}$ was $67.4 \mathrm{~mol} \%$. This value is within the range for the genus Lysobacter (Christensen \& Cook, 1978). The major quinone for the novel strain was Q-8 and this quinone has also been reported as the major quinone for all of the type strains of recognized members of the genus Lysobacter.

The 16S rRNA gene sequence of strain $\mathrm{YC} 6269^{\mathrm{T}}$ was a continuous stretch of $1415 \mathrm{bp}$. Sequence similarity calculations after a neighbour-joining analysis indicated that the closest relatives of the novel strain were $L$. yangpyeongensis DSM $17635^{\mathrm{T}}(98.6 \%)$, L. niabensis GH34-4 ${ }^{\mathrm{T}}(97.2 \%), L$. enzymogenes DSM $2043^{\mathrm{T}}(96.9 \%)$, L. daejeonensis DSM $17634^{\mathrm{T}}(96.3 \%)$ and L. niastensis $\mathrm{GH} 41-7^{\mathrm{T}}(96.2 \%)$. Other species of the genus had low similarity values of $<96.0 \%$. The phylogenetic trees based on the neighbour-joining and maximum-parsimony methods (Fig. 1) showed that strain YC $6269^{\mathrm{T}}$ formed a cluster with the closely related species of the genus Lysobacter, supported by a high bootstrap value (89\%). DNA-DNA hybridization levels between strain ${\text { YC } 6269^{\mathrm{T}}}^{\mathrm{T}}$ and L. yangpyeongensis DSM $17635^{\mathrm{T}}$ and $L$. niabensis $\mathrm{GH} 34-4^{\mathrm{T}}$ were 45.0 and $18.0 \%$, respectively, which revealed that strain $\mathrm{YC} 6269^{\mathrm{T}}$ belongs to a distinct genomic species (Wayne et al., 1987; Stackebrandt and Goebel, 1994).

Low levels of DNA-DNA hybridization, phylogenetic analysis (Fig. 1), enzymic activities, differences in other physiological and biochemical characteristics (Table 1 and Supplementary Table S1), antibiotic-sensitivity and the fatty acid profile (Supplementary Table S2) clearly distinguish strain YC6269 $9^{\mathrm{T}}$ from all the recognized species of the genus Lysobacter. Thus, on the basis of the evidence given above, we propose that strain $\mathrm{YC} 6269^{\mathrm{T}}$ represents the type strain of a novel species of the genus Lysobacter, Lysobacter oryzae sp. nov.

\section{Description of Lysobacter oryzae sp. nov.}

Lysobacter oryzae (o.ry'zae. L. gen. n. oryzae of rice, pertaining to the isolation of the type strain from the rhizosphere of rice).

Cells are Gram-negative, facultatively anaerobic, short rodshaped, non-spore-forming, non-motile (but have gliding activity) and are $0.3-0.5 \mu \mathrm{m}$ wide $\times 1.8-2.0 \mu \mathrm{m}$ long. Cells occur singly and in pairs. Colonies grown on half-strength $\mathrm{R} 2 \mathrm{~A}$ agar at $28{ }^{\circ} \mathrm{C}$ for 3 days are $1-2 \mathrm{~mm}$ in diameter, pale yellow, smooth and circular. The temperature range for growth is $15-42{ }^{\circ} \mathrm{C}$, optimum temperature for growth is $28{ }^{\circ} \mathrm{C}$. The $\mathrm{pH}$ growth range is between 5.5 and 11.0, with an optimum of $\mathrm{pH} 7.0-8.0$. Growth occurs in the absence of $\mathrm{NaCl}$ in half-strength $\mathrm{R} 2 \mathrm{~A}$ medium and no growth occurs in $1.0 \%(\mathrm{w} / \mathrm{v}) \mathrm{NaCl}$. Resistant to $10 \mu \mathrm{g} \mathrm{ml}^{-1}$ of tetracycline, kanamycin, streptomycin and rifampicin, but sensitive to $10 \mu \mathrm{g} \mathrm{ml}^{-1}$ ampicillin. Catalase- and oxidase- 
Table 1. Differential phenotypic characteristics between strain YC6269 ${ }^{\top}$ and related species of the genus $L y s o b a c t e r$

Taxa: 1, strain YC6269 ${ }^{\mathrm{T}} ; 2$, L. yangpyeongensis DSM $17635^{\mathrm{T}} ; 3$, L. niabensis GH34-4 ${ }^{\mathrm{T}}$ (data from Weon et al., 2007); 4, L. koreensis Dae16 ${ }^{\mathrm{T}}$; 5, L. daejeonensis DSM $17634^{\mathrm{T}}$; 6, L. gummosus KCTC $12132^{\mathrm{T}}$; 7, L. antibioticus KCTC $12129^{\mathrm{T}}$; 8, L. enzymogenes KCTC $12131^{\mathrm{T}}$. All data are from this study unless otherwise indicated. ND, Not determined; +, positive; \pm , weak; - , negative. All of the strains tested are able to hydrolyse casein and gelatin, but not agar or urea.

\begin{tabular}{|c|c|c|c|c|c|c|c|c|}
\hline Characteristic & 1 & 2 & 3 & 4 & 5 & 6 & 7 & 8 \\
\hline Cell size $(\mu \mathrm{m})$ & $0.3-0.5 \times$ & $0.4-0.6 \times$ & $0.5 \times$ & $0.5-0.8 \times$ & $0.4-0.6 \times$ & $0.4 \times$ & $0.4 \times$ & $0.5 \times$ \\
\hline & $1.8-2.0$ & $3.0-4.0^{\star a}$ & $2.0-5.0$ & $1.5-2.0^{b}$ & $3.0-4.0^{a}$ & $2.0^{a}$ & $6.5^{a}$ & $38.0^{a}$ \\
\hline Colony type & Smooth & Smooth & Irregular & Smooth & Smooth & Smooth & Mucoid & Smooth \\
\hline Colony colour $\dagger$ & PY & $\mathrm{Y}$ & $\mathrm{Y}$ & $\mathrm{Y}$ & $\mathrm{Y}$ & PYG & $\mathrm{C}$ & DY-C \\
\hline Aerobic/facultatively anaerobic $\neq$ & $\mathrm{F}$ & A & A & A & A & $\mathrm{F}$ & $\mathrm{F}$ & $\mathrm{F}$ \\
\hline \multicolumn{9}{|c|}{$\mathrm{NaCl}$ concentration for growth $(\% \mathrm{w} / \mathrm{v})$ : } \\
\hline Optimum & 0 & $0^{a}$ & 0 & $0^{b}$ & $0^{a}$ & $0^{c}$ & $0^{c}$ & $0^{c}$ \\
\hline Range & 0 & $0-1.0^{a}$ & $0-1.0$ & $0-2.0^{b}$ & $0-3.0^{a}$ & $0-2.0^{c}$ & $0-1.0^{c}$ & $0-1.0^{c}$ \\
\hline No growth & 1.0 & $2.0^{a}$ & 2.0 & $3.0^{b}$ & $\mathrm{ND}^{a}$ & $3.0^{c}$ & $3.0^{c}$ & $3.0^{c}$ \\
\hline Catalase & + & - & + & + & - & + & + & + \\
\hline Oxidase & + & + & + & - & + & + & + & + \\
\hline \multicolumn{9}{|l|}{ API ZYM kit: } \\
\hline$\alpha$-Chymotrypsin & + & - & \pm & - & - & - & - & + \\
\hline Trypsin & + & + & - & - & + & - & - & + \\
\hline$\alpha$-Glucosidase & + & + & - & - & + & - & - & + \\
\hline$N$-Acetyl- $\beta$-glucosaminidase & - & + & + & - & - & + & + & - \\
\hline \multicolumn{9}{|l|}{ Hydrolysis of: } \\
\hline Chitin & - & - & - & - & - & + & + & + \\
\hline Starch & - & + & + & - & - & - & - & - \\
\hline Tween 20 & - & + & $\mathrm{ND}$ & + & + & + & + & + \\
\hline \multicolumn{9}{|l|}{ Growth on/at: } \\
\hline Citrate & - & - & - & + & - & + & + & + \\
\hline D-Glucose & - & - & - & - & + & + & - & + \\
\hline Arabinose & - & - & - & + & - & + & - & - \\
\hline Maltose & - & - & - & - & + & + & + & + \\
\hline pH 4 & - & - & - & ND & - & + & - & \pm \\
\hline $\mathrm{pH} 10$ & + & - & - & $\mathrm{ND}$ & - & - & - & + \\
\hline MacConkey agar & - & - & - & - & - & - & - & + \\
\hline EMB agar\$ &,+ PI & - & - &,+ PI & - &,+ PI &,$+ \mathrm{PI}$ &,$+ \mathrm{PI}$ \\
\hline DNA G $+\mathrm{C}$ content $(\mathrm{mol} \%)$ & 67.4 & $67.3^{a}$ & 62.5 & $68.9^{b}$ & $61.7^{a}$ & $65.7^{c}$ & $69.2^{c}$ & $69.0^{c}$ \\
\hline
\end{tabular}

${ }^{\star}$ Data taken from other studies as indicated: ${ }^{a}$ Weon et al. $(2006) ;{ }^{b} \mathrm{~J}$. W. Lee et al., 2006; ${ }^{c}$ Christensen \& Cook (1978).

$\dagger$ DY, deep yellow; PYG, pale yellowish-grey; PY, pale yellow; Y, yellow; c, cream.

$\ddagger$, Aerobic; F, facultative anaerobic.

§Colour of growth indicated as: PI, pink. EMB, Eosin methylene blue.

positive. Hydrolyses casein, hippurate and gelatin but does not hydrolyse elastin, guanine, adenine, aesculin, starch or Tween 20. Utilizes 5-bromo-3-indoxyl-nonanoate, 4-nitrophenyl $\alpha$-D-glucopyranoside and 4-nitrophenyl- $\alpha$-D-maltopyranoside as a single carbon source but not the following: L-arabitol, galacturonic acid, potassium 5ketogluconate, sodium pyruvate, D-mannitol, maltose, potassium gluconate, capric acid, adipic acid, malic acid, citrate, phenylacetic acid, adonitol, palatinose, L-tryptophan, 5-bromo-4-chloro-3-indolyl- $N$-acetyl- $\beta$-D-glucosaminide, 4-nitrophenyl- $\beta$-D-glucopyranoside, 4-nitrophenyl- $\beta$-D-glucuronide, 4 -nitrophenyl- $\alpha$-D-galactopyranoside, sodium malonate, D-glucose, D-mannose, sucrose,
L-arabinose, D-arabitol, trehalose, D-rhamnose, inositol, cellobiose or D-sorbitol. Acid is not produced from glucose, inositol, D-mannitol, sorbitol, rhamnose, melibiose, amygdalin, sucrose or L-arabinose. Urea is not hydrolysed. Indole and $\mathrm{H}_{2} \mathrm{~S}$ are not produced. Acetoin is produced. Nitrate is not reduced to nitrite or nitrogen gas. Positive in tests for activities of alkaline phosphatase, esterase (C-4), esterase lipase (C-8), leucine arylamidase, valine arylamidase, trypsinase, $\alpha$-chymotrypsin, acid phosphatase, naphthol-AS-Bl-phosphohydrolase and $\alpha$-glucosidase, but not for lipase (C-14), cystine arylamidase, $\beta$-glucosidase, $\alpha$ galactosidase, $\beta$-galactosidase, $\beta$-glucuronidase, $N$-acetyl$\beta$-glucosaminidase, $\alpha$-mannosidase or $\alpha$-fucosidase. Q- 8 is 


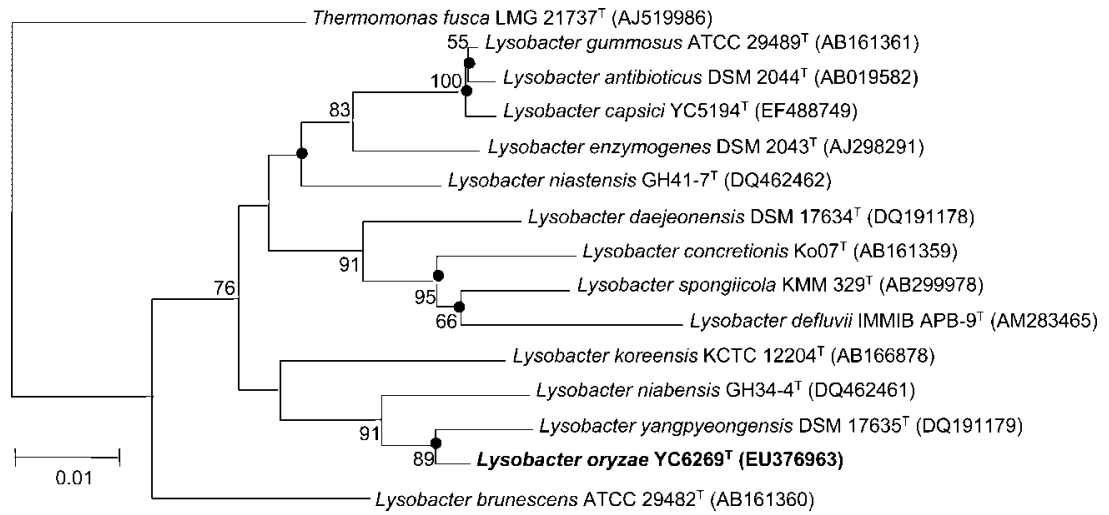

Fig. 1. Phylogenetic tree constructed from comparative analysis of $16 \mathrm{~S}$ rRNA gene sequences showing the relationships between strain $Y C 6269^{\top}$ and related species of the genus Lysobacter. The tree was constructed by using the neighbour-joining method and Jukes \& Cantor evolutionary distance matrix data obtained from aligned nucleotides. Solid circles indicate that the corresponding clades were also recovered in maximum-parsimony trees. Bootstrap values (expressed as percentage of 1000 replications) greater than $50 \%$ are shown at the branch points. Bar, 1 substitution per 100 nucleotide positions. the major quinone. The major polar lipids are phosphatidylethanolamine, phosphatidylglycerol and phosphatidyl$\mathrm{N}$-methylethanolamine.

The type strain, YC6269 $9^{\mathrm{T}}\left(=\right.$ KCTC $\left.22249^{\mathrm{T}}=\mathrm{DSM} 21044^{\mathrm{T}}\right)$, was isolated from the rhizosphere of rice managed under no-tillage practice in Jinju, Korea. The DNA G + C content of the type strain is $67.4 \mathrm{~mol} \%$.

\section{Acknowledgements}

This work was supported by a Brain Korea (BK) 21 project in 2006-2007 and Z.A. and M.Y. were supported by a scholarship from the BK21 Program, the Ministry of Education and Human Resources Development, Korea. We are thankful to Dr Soon-Wo Kwon (KACC, Suwon, Korea), who provided unpublished data for Lysobacter niabensis.

\section{References}

Ahmed, K., Chohnan, S., Ohashi, H., Hirata, T., Masaki, T. \& Sakiyama, F. (2003). Purification, bacteriolytic activity, and specificity of $\beta$-lytic protease from Lysobacter sp. IB-9374. J Biosci Bioeng 95, $27-34$.

Atlas, R. M. (1993). Handbook of Microbiological Media. Edited by L. C. Parks. Boca Raton, FL: CRC Press.

Ausubel, F. W., Brent, R., Kingston, R. E., Moore, D. D., Seidman, J. G., Smith, J. A. \& Struhl, K. (1995). Current Protocols in Molecular Biology. New York: Wiley.

Brown, A. E. (2007). Benson's Microbiological Applications. In Laboratory Manual in General Microbiology. New York: McGraw-Hill, Janice Roerig-Blong.

Cappuccino, J. G. \& Sherman, N. (2002). Microbiology: a Laboratory Manual, 6th edn. Menlo Park, CA: Benjamin/Cummings.

Chohnan, S., Nonaka, J., Teramoto, K., Taniguchi, K., Kameda, Y., Tamura, H., Kurusu, Y., Norioka, S., Masaki, T. \& Sakiyama, F. (2002). Lysobacter strain with high lysyl endopeptidase production. FEMS Microbiol Lett 213, 13-20.

Christensen, P. \& Cook, F. D. (1978). Lysobacter, a new genus of nonfruiting, gliding bacteria with a high base ratio. Int J Syst Bacteriol 28, 367-393.

Chung, Y. R., Sung, K. C., Mo, H. K., Son, D. Y., Nam, J. S., Chun, J. \&

Bae, K. S. (1999). Kitasatospora cheerisanensis sp. nov., a new species of the genus Kitasatospora that produces an antifungal agent. Int J Syst Bacteriol 49, 753-758.

Costilow, R. N. (1981). Biophysical factors in growth. In Manual of Methods for General Bacteriology, pp. 66-78. Edited by P. Gerhardt, R. G. E. Murray, R. N. Costilow, E. W. Nester, W. A. Wood, N. R. Krieg \& G. B. Phillips. Washington, DC: American Society for Microbiology.

Ezaki, T., Hashimoto, Y. \& Yabuuchi, E. (1989). Fluorometric deoxyribonucleic acid-deoxyribonucleic acid hybridization in microdilution wells as an alternative to membrane filter hybridization in which radioisotopes are used to determine genetic relatedness among bacterial strains. Int J Syst Bacteriol 39, 224-229.

Felsenstein, J. (1985). Confidence limits on phylogenies: an approach using the bootstrap. Evolution 39, 783-791.

Fitch, W. M. (1971). Toward defining the course of evolution: minimum change for a specific tree topology. Syst Zool 20, 406-416.

Folman, L. B., Postma, J. \& Veen, J. A. V. (2001). Ecophysiological characterization of rhizosphere bacterial communities at different root locations and plant developmental stages of cucumber grown on rockwool. Microb Ecol 42, 586-597.

Folman, L. B., De Klein, M. J. E. M., Postma, J. \& van Veen, J. A. (2004). Production of antifungal compounds by Lysobacter enzymogenes isolate 3.1T8 under different conditions in relation to its efficacy as a biocontrol agent of Pythium aphanidermatum in cucumber. Biol Control 31, 145-154.

Hall, T. A. (1999). BioEdit: a user-friendly biological sequence alignment editor and analysis program for Windows 95/98/NT. Nucleic Acids Symp Ser 41, 95-98.

Hamaki, T., Suzuki, M., Fudou, R., Jojima, Y., Kajiura, T., Tabuchi, A., Sen, K. \& Shibai, H. (2005). Isolation of novel bacteria and actinomycetes using soil-extract agar medium. J Biosci Bioeng 99, 485-492.

Hashizume, H., Hattor, S., Igarashi, M. \& Akamatsu, Y. (2004). Tripropeptin E, a new Tripropeptin group antibiotic produced by Lysobacter sp. BMK333-48F3. J Antibiot (Tokyo) 57, 394-399.

Islam, M. T., Hashidoko, Y., Deora, A., Ito, T. \& Tahara, S. (2005). Suppression of damping-off disease in host plants by the rhizoplane bacterium Lysobacter sp. strain SB-K88 is linked to plant colonization and antibiosis against soilborne Peronosporomycetes. Appl Environ Microbiol 71, 3786-3796.

Janssen, P. H., Yates, P. S., Grinton, B. E., Taylor, P. M. \& Sait, M. (2002). Improved culturability of soil bacteria and isolation in pure culture of novel members of the divisions Acidobacteria, 
Actinobacteria, Proteobacteria, and Verrucomicrobia. Appl Environ Microbiol 68, 2391-2396.

Joseph, S. J., Hugenholtz, P., Sangwan, P., Osborne, C. A. \& Janssen, P. H. (2003). Laboratory cultivation of widespread and previously uncultured soil bacteria. Appl Environ Microbiol 69, 72107215.

Kato, A., Nakaya, S., Kokubo, N., Aiba, Y., Ohashi, Y. \& Hirata, H. (1998). A new anti-MRSA antibiotic complex, WAP-8294A. J Antibiot (Tokyo) 51, 929-935.

Kilic-Ekici, O. \& Yuen, G. Y. (2003). Induced resistance as a mechanism of biological control by Lysobacter enzymogenes strain C3. Biol Control 93, 1103-1110.

Kimura, M. (1983). The Neutral Theory of Molecular Evolution. Cambridge: Cambridge University Press.

Kinyon, J. M. \& Harris, D. L. (1979). Treponema innocens, a new species of intestinal bacteria, and emended description of the type strain of Treponema hyodysenteriae Harris et al. Int J Syst Bacteriol 29, 102109.

Lane, D. J. (1991). 16S/23S rRNA sequencing. In Nucleic Acid Techniques in Bacterial Systematics, pp. 115-175. Edited by E. Stackebrandt \& M. Goodfellow. Chichester: Wiley.

Lechevalier, M. P., De Bièvre, C. \& Lechevalier, H. A. (1977). Chemotaxonomy of aerobic actinomycetes: phospholipid composition. Biochem Syst Ecol 5, 249-260.

Lee, J. W., Im, W.-T., Kim, M. K. \& Yang, D.-C. (2006a). Lysobacter koreensis sp. nov., isolated from a ginseng field. Int J Syst Evol Microbiol 56, 231-235.

Lee, M. S., Do, J. O., Park, M. S., Jung, S., Lee, K. H., Bae, K. S., Park, S. J. \& Kim, S. B. (2006b). Dominance of Lysobacter sp. in the rhizosphere of two coastal sand dune plant species, Calystegia soldanella and Elymus mollis. Antonie van Leeuwenhoek 90, 19-27.

Lueders, T., Kindler, R., Miltner, A., Friedrich, M. W. \& Kaestner, M. (2006). Identification of bacterial micropredators distinctively active in a soil microbial food web. Appl Environ Microbiol 72, 5342-5348.

Mesbah, M., Premachandran, U. \& Whitman, W. B. (1989). Precise measurement of the $\mathrm{G}+\mathrm{C}$ content of deoxyribonucleic acid by highperformance liquid chromatography. Int J Syst Bacteriol 39, 159-167.

Nakayama, T., Homma, Y., Hashidoko, Y., Mizutani, J. \& Tahara, S. (1999). Possible role of xanthobaccins produced by Stenotrophomonas sp. strain SB-K88 in suppression of sugar beet damping-off disease. Appl Environ Microbiol 65, 4334-4339.

Ohman, D. E., Cryz, S. J. \& Iglewski, B. H. (1980). Isolation and characterization of a Pseudomonas aeruginosa PAO mutant that produces altered elastase. J Bacteriol 142, 836-842.

Park, J. H., Kim, R., Aslam, Z., Jeon, C. O. \& Chung, Y. R. (2008). Lysobacter capsici sp. nov., with antimicrobial activity, isolated from the rhizosphere of pepper, and emended description of the genus Lysobacter. Int J Syst Evol Microbiol 58, 387-392.

Romanenko, L. A., Uchino, M., Tanaka, N., Frolova, G. M. \& Mikhailov, V. V. (2008). Lysobacter spongiicola sp. nov., isolated from a deep-sea sponge. Int J Syst Evol Microbiol 58, 370-374.

Saitou, N. \& Nei, M. (1987). The neighbor-joining method: a new method for reconstructing phylogenetic trees. Mol Biol Evol 4, 406425.

Stackebrandt, E. \& Goebel, B. M. (1994). Taxonomic note: a place for DNA-DNA reassociation and $16 \mathrm{~S}$ rRNA sequence analysis in the present species definition in bacteriology. Int J Syst Bacteriol 44, 846849.

Tamura, K., Dudley, J., Nei, M. \& Kumar, S. (2007). MEGA4: molecular evolutionary genetics analysis (MEGA) software version 4.0. Mol Biol Evol 24, 1596-1599.

Ten, L. N., Im, W. T., Kim, M. K., Kang, M. S. \& Lee, S. T. (2004). Development of a plate technique for screening of polysaccharidedegrading microorganisms by using a mixture of insoluble chromogenic substrates. J Microbiol Methods 56, 375-382.

Thompson, J. D., Gibson, T. J., Plewniak, F., Jeanmougin, F. \& Higgins, D. G. (1997). The ClustaL_X Windows interface: flexible strategies for multiple sequence alignment aided by quality analysis tools. Nucleic Acids Res 25, 4876-4882.

Tindall, B. J. (1990). Lipid composition of Halobacterium lacusprofundi. FEMS Microbiol Lett 66, 199-202.

Wallace, R. J., Jr, Brown, B. A., Blacklock, Z., Ulrich, R., Jost, K., Brown, J. M., McNeil, M. M., Onyi, G., Steingrube, V. A. \& Gibson, J. (1995). New Nocardia taxon among isolates of Nocardia brasiliensis associated with invasive disease. J Clin Microbiol 33, 1528-1533.

Wayne, L. G., Brenner, D. J., Colwell, R. R., Grimont, P. A. D., Kandler, O., Krichevsky, M. I., Moore, L. H., Moore, W. E. C., Murray, R. G. E. \& other authors (1987). International Committee on Systematic Bacteriology. Report of the ad hoc committee on reconciliation of approaches to bacterial systematics. Int J Syst Bacteriol 37, 463-464.

Weon, H.-Y., Kim, B.-Y., Baek, Y.-K., Yoo, S.-H., Kwon, S.-W., Stackebrandt, E. \& Go, S.-J. (2006). Two novel species, Lysobacter daejeonensis sp. nov. and Lysobacter yangpyeongensis sp. nov., isolated from Korean greenhouse soils. Int J Syst Evol Microbiol 56, 947-951.

Weon, H.-Y., Kim, B.-Y., Kim, M.-K., Yoo, S.-H., Kwon, S.-W., Go, S.-J. \& Stackebrandt, E. (2007). Lysobacter niabensis sp. nov. and Lysobacter niastensis sp. nov., isolated from greenhouse soils in Korea. Int J Syst Evol Microbiol 57, 548-551.

Yassin, A. F., Chen, W. M., Hupfer, H., Siering, C., Kroppenstedt, R. M., Arun, A. B., Lai, W. A., Shen, F. T., Rekha, P. D. \& Young, C. C. (2007). Lysobacter defluvii sp. nov., isolated from municipal solid waste. Int J Syst Evol Microbiol 57, 1131-1136. 